\title{
Work Life Balance of Women Employees of it Sector during Remote Working
}

\author{
C. Naga Ganesh, Nagaraja. P., P. Sumalatha
}

\begin{abstract}
In this paper, an endeavor has been made to track down the professional and the personal difficulties and enhancers for work life balance among working women during work from home through a study of 100 ladies working in the IT area in India. The primary difficulties in professional life were discovered to be expanded working hours, travel time from home to work place, and additional tasks engaged by them. Where as in personal life, the primary anxieties were blame from elders for not being taken care of family. Most of the women would incline toward adaptable planning, flexi-time, and strong spouse, family, and companions just as a climate helpful for work at the workplace.

Key Words: Work Life Balance, Work from Home, Women
\end{abstract} Employees, Personal and Professional Life.

\section{INTRODUCTION}

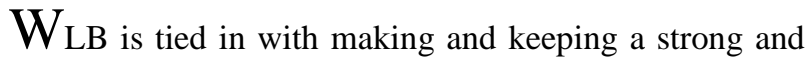
sound workplace that causes employees to have harmony among individual and expert life. This will assist with expanding employee dedication and efficiency. In the present living world, both men and women, similarly share the duties of procuring for the better settlement of their dayto-day life. It is hard for women to keep harmony among individual and work life than men with expanded work pressure. An individual life can likewise be requesting if employees have a child or maturing guardian. The work trouble is more on women shoulders regarding family assumptions, dealing with the home, dealing with kids and guardians. The work-life imbalance or irregularity may prompt non-attendance from work and making pressure. Work and day-to-day life are two of a kind for Women. On one side, the requests of her work give her less an ideal opportunity for her family and on the opposite side, her family obligations influence her enthusiasm for work. Accordingly, the issue of balance between work and life during work from home should be tended to from the two sides i.e., the company or organization point and from the family viewpoint. This research attempts to realize the issues looked at by them and to recognize the activities embraced by the organizations for advancing WLB.

Manuscript received on March 09, 2021

Revised Manuscript received on March 15, 2021

Manuscript published on March 30, 2021.

* Correspondence Author

Dr. C. Naga Ganesh*, Assistant Professor, G. Pullaiah College of Engineering and Technology, Kurnool (AP), India.

Dr. Nagaraja. P, Associate Professor, Dr. B. R. Ambedkar Institute of Management and Technology, Hyderabad (Telangana), India.

P. Sumalatha, Assistant Professor, Dr. B. R. Ambedkar Institute of Management and Technology, Hyderabad (Telangana), India.

(C) The Authors. Published by Blue Eyes Intelligence Engineering and Sciences Publication (BEIESP). This is an open access article under the CC BY-NC-ND license (http://creativecommons.org/licenses/by-nc-nd/4.0/)

\section{LITERATURE REVIEW}

Alegre and Patamar (2018): examined another idea and advantages of work life balance which spotlight the creativity of a representative i.e., the utilization of propelling innovation in performing assignments both at work and at the individual front.

They additionally investigated that associations should offer their representatives commitment, inspiration, and interfacing imagination in the work environment. Tiwari (2017): Obviously called attention to that representatives, particularly ladies, need to assume a twofold part in their life, one in the work environment and the other at home. The investigation was directed in private associations comprising of an example size of 150 female representatives. It was understood that $93.32 \%$ of representatives feel that the changing climate and difficulties related to it, are preventing both work and day to day life. Additionally, 56.67\% of workers felt that their hierarchical culture and directors are not steady to assist representatives with dealing with their own and expert life. Then again, 83.32\% of workers get total help from family to seek after a task and helping out family commitments.

Shaffer et al (2016): Work-life balance envelopes a harmony between two altogether separate jobs performed by an individual specifically the jobs of work and the jobs of family, and to holders of the jobs, both bring fulfillment.

Joanna Hughes, Nikos Bozines' (2015): Design is to investigate the perspectives of male specialists in a maleruled occupation on issues that relate to equilibrium between fun and serious stuff.

It arose that work-life awkwardness was a wellspring of worry as well as that it was the significant wellspring of a disappointment for members. Besides, members made an unmistakable association between issues with harmony between serious and fun times and withdrawal practices, including turnover and non-authentic debilitated nonappearance.

Au and Ahmed, (2014): The administration of equilibrium between fun and serious stuff and additionally work-family struggle interest of representatives have been discovered to be among the essential perspectives to be tended to by the association as an approach to safeguard the HR.

Purohit (2013): had done an investigation among representatives of driving corporate substances addressing, producing, data innovation, instructive, and banking areas in the Pune locale in India and focused on the way that authoritative arrangement estimates supporting harmony between serious and fun times are vital for accomplishing common advantages between the worker and the representatives.

Published By:

Blue Eyes Intelligence Engineering

\& Sciences Publication

(C) Copyright: All rights reserved.

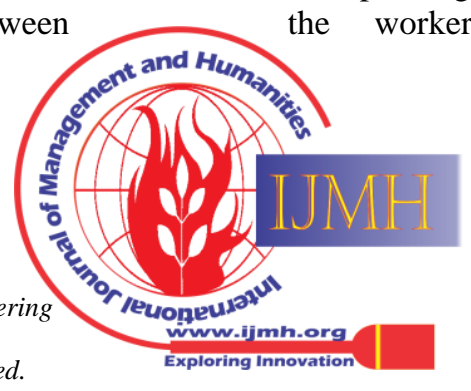




\section{Work Life Balance of Women Employees of It Sector during Remote Working}

Fatima et.al (2012): factors influencing equilibrium between fun and serious stuff are accomplice support partner backing and occupation assets are emphatically connected with the equilibrium between fun and serious stuff though baseless analysis at the specific employment is adversely connected with harmony between serious and fun times.

The examination uncovers that concerning accomplice support male representatives are happier with an equilibrium between fun and serious stuff when contrasted with females. It is tracked down that female representative felt more worklife strain because of childcare duties, and it is additionally seen that senior reliance is multiplying the weight of ladies than men.

Murphy and Doherty (2011): uncovered that it is unimaginable to expect to quantify harmony between serious and fun times in a flat-out manner as there are close to home conditions that impact the way that is seen yet set up an agreement that mirrors a person's needs through representatives should draw a firm line between their home and work lives and be certain that the line is in the ideal spot.

Doble and Suraya (2010): researched equilibrium between fun and serious stuff across sexes and saw that the two guys and females confronted irregularity in family and work life. The investigation portrayed the elements that added to harmony between serious and fun times like strategic scheduling, telecommute, low maintenance work, accessibility of childcare, and adaptability to deal with crises at home.

Rebecca Bandhan (2009): Women and men by and large have an alternate impression of what the "life" some portion of the equilibrium includes. For ladies, it will in general be dedicating more opportunity to family, while for men it is investing more energy seeking after close to home interests.

\section{OBJECTIVES}

1. To recognize the problems faced by women while balancing work and life during remote working in IT sector.

2. To know the strategies implemented by the organization to balance the work life in remote working.

3. To know the employee's perspective on work life balance during work from home and work from office.

\section{SCOPE OF THE STUDY}

In the current situation, because of numerous progressions occurring in the work environment and family frameworks, a larger part of women is thinking that it's hard to accomplish an ideal equilibrium between personal and professional life. In correlation with men, ladies have more obligations at home. Despite the fact that there are concentrates on WLB, moderately there are fewer examinations on WLB of women employees. Hence, there is and day-to-day life in the IT area. The current investigation is kept to women employees in Hyderabad city. Women employees who have been working in the IT area were considered with the end goal of the examination. a need to concentrate on how ladies are adjusting their work

\section{METHODOLOGY}

The study was completed based on both the primary and secondary data resources. Endeavors were made to gather the real time responses / reaction around "WLB of Women employees working in IT industry during work from home". The primary information, collected through a structured questionnaire, was created to gather the reactions from the women employees working in the IT area. Also, the secondary information was gathered from Literature reports and other information are gathered from diaries, magazines, and other distributed information. The sample size considered for the investigation is 100 respondents.

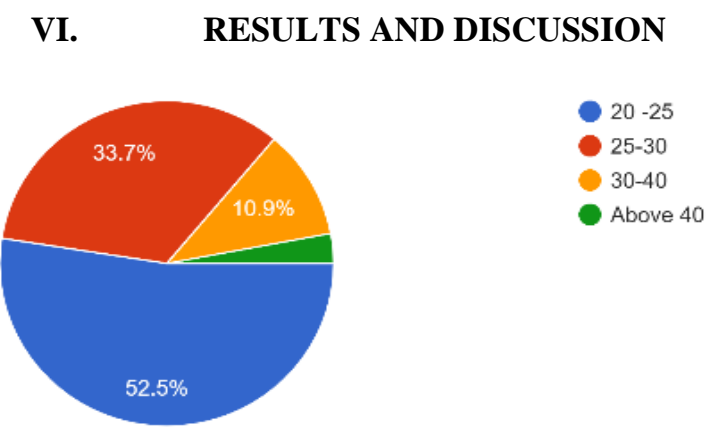

Figure-1: Demographic profile of the respondents

The above figure shows that $52.5 \%$ of the employees are of age group 20-25, 33.7\% of the employees are of age group 25-30, Only $10.9 \%$ employees are $30-40$ years old.

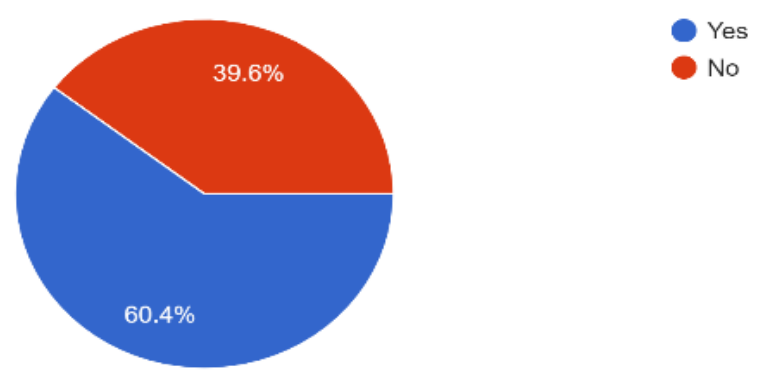

Figure-2: Marital Status of the respondents

From the above figure, it is clear that $60.4 \%$ of the spouse are working and $39.6 \%$ are unemployed.

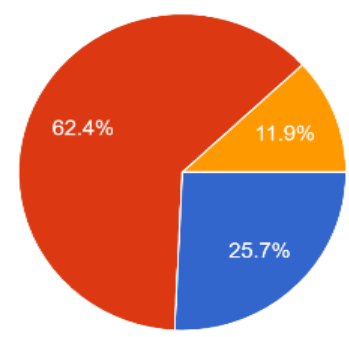

$$
\begin{aligned}
& \text { Very well balanced } \\
& \text { Partially balanced } \\
& \text { Unbalanced }
\end{aligned}
$$

Figure-3: Balance between Personal and Professional Life

The above figure shows that $62.4 \%$ employees are partially balancing their work life and $25.7 \%$ are balancing very well where as $11.9 \%$ are unable to balance. 


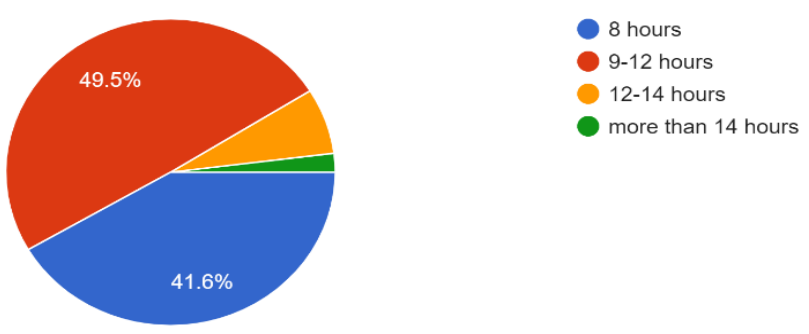

Figure-4: Working hours per day

The above figure shows that $49.5 \%$ of the employees are working for 9-12 hours per day and $41.6 \%$ are working for 8 hours.

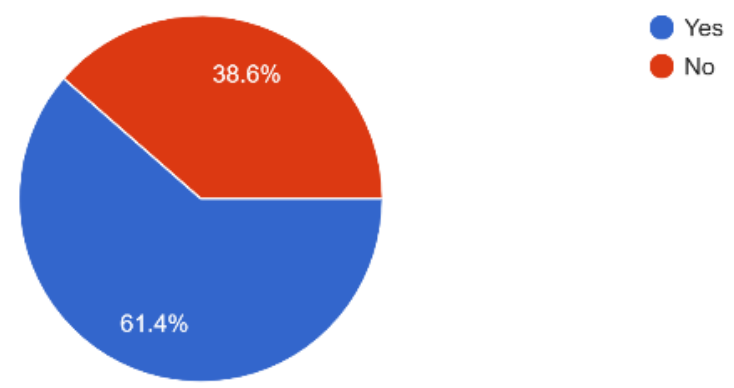

Figure-5: Feelings of respondents while they work The above figure shows that $61.4 \%$ of employees can get isolated space to work and $38.6 \%$ are unable to get the space to work.

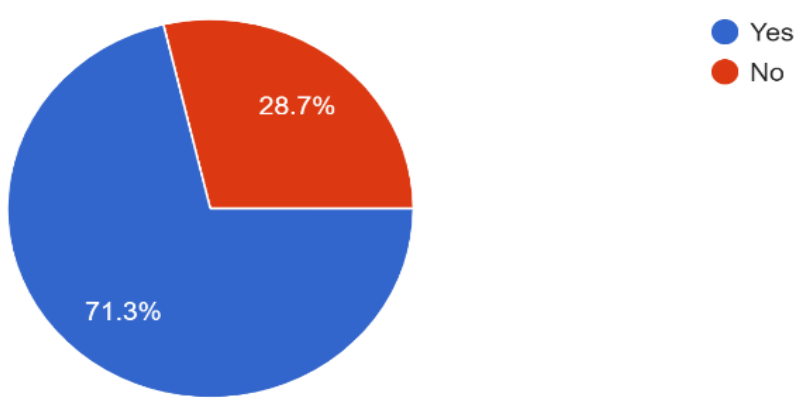

Figure-6: Pressure at Work

The above figure shows that $71.3 \%$ of employees are able to submit the work in time by balancing work and life. $28.7 \%$ of employees are unable to submit their work.

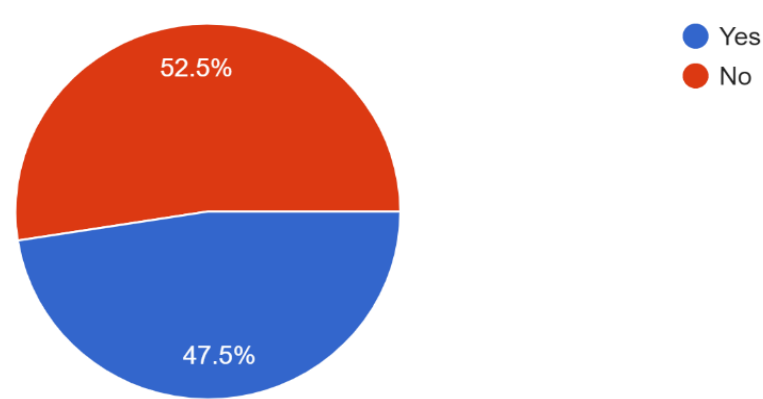

Figure-7: Work Culture/ambience

The above figure shows that $52.5 \%$ have healthy work life balance and $47.5 \%$ doesn't have healthy work life balance.

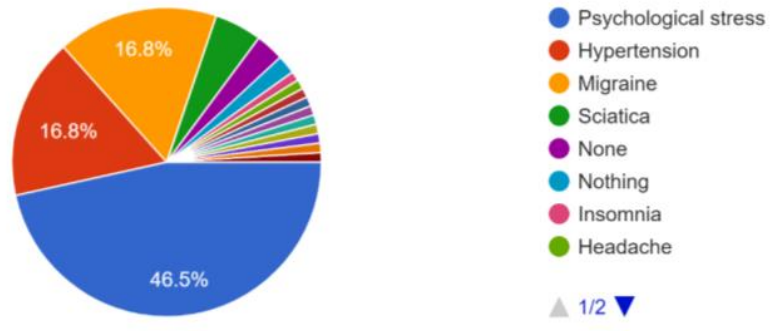

Figure-8: Health and Safety Measures While working from Home

The above figure show that $46.5 \%$ of employees are facing psychological stress and $16.8 \%$ of employees are suffering from migraine and the same number of employees are suffering from hypertension during remote working.
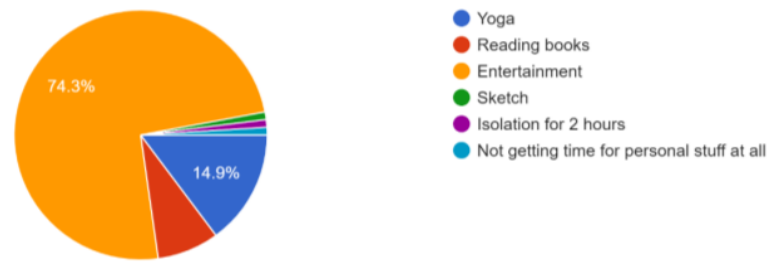

Figure-9: Management of Stress - WFM

The above figure show that $74.3 \%$ of the employees goes for entertainment when they feel stress whereas only $14.9 \%$ do yoga.

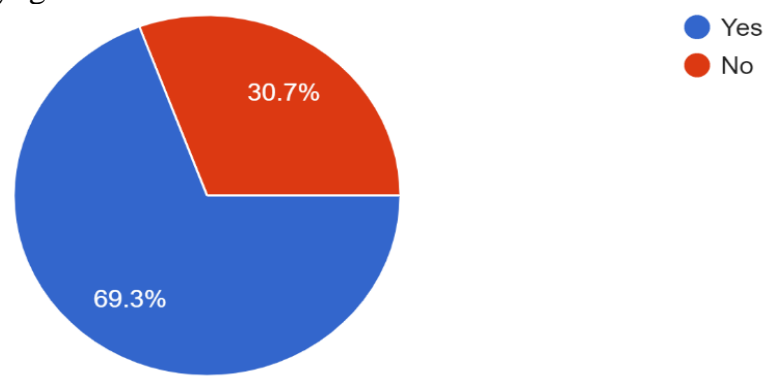

Figure-10: Supportive measures to maintain WLB

The above figure show that $69.3 \%$ of the employees stated that their management provides supportive measures to maintain work life balance.

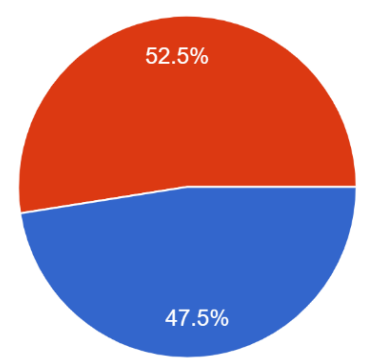

Specified timings

Flexible timings

Figure-11: Pressure on completing targets while WFM

The above figure shows that $52.5 \%$ of employees are allowed to work in flexible hours whereas $47.5 \%$ are asked to submit work in specified timings.

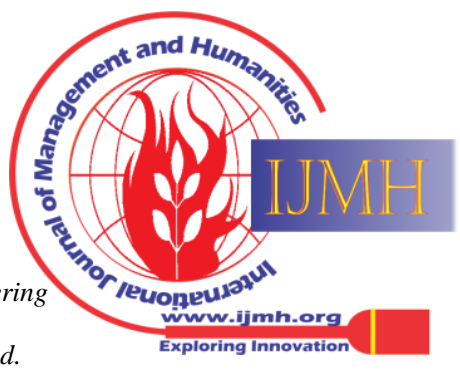




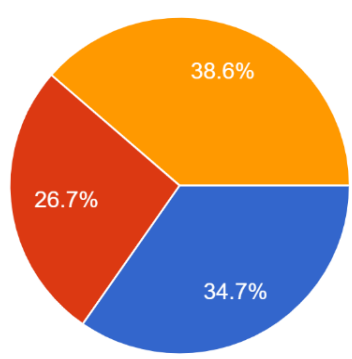

Figure-12: Best Alternative for Work

The above figure shows that $26.7 \%$ of employees are willing to work form office and $34.7 \%$ are willing to work from home whereas $38.6 \%$ are willing to work either from office or from home.

\begin{tabular}{l} 
Table-1: Factors which influence WLB While WFM \\
\begin{tabular}{|c|c|}
\hline Factors of WLB & $\begin{array}{c}\text { Multiple Regression R } \\
\text { values }\end{array}$ \\
\hline Finishing targets on Time & .412 \\
\hline $\begin{array}{c}\text { Psychological Pressure } \\
\text { from Family }\end{array}$ & .362 \\
\hline Child Care/Parenting & .421 \\
\hline Technical Issues & .879 \\
\hline $\begin{array}{c}\text { Isolation feeling while } \\
\text { work/No commitment }\end{array}$ & .652 \\
\hline Disturbed health/Mindset & .712 \\
\hline R2 & .698 \\
\hline Adjusted R & .688 \\
\hline F & 30.1204 \\
\hline
\end{tabular} \\
\hline
\end{tabular}

The results clearly mentions that women employees are facing much problems from child care, health issues and technical issues while they work from Home. Majority of the women employees are interested to work from office only.

\section{CONCLUSION}

Women employees establish a significant segment of the working environment. In any case, the current circumstance of countless capable ladies who because of different conditions have been avoided with regard to their positions should be tended to. The issues confronted are a few at the same time, essentially frequently the break in their transporter emerges out of parenthood and family obligations. Accomplishing a decent harmony among work and family responsibilities is a developing worry for contemporary employees and organizations. It is trusted that this task report will shape a venturing stone simultaneously and give a premise to reflection and discussion on the WLB issues among ladies in the IT area.

\section{REFERENCES}

1. Anita, K. and Uma Maheshwari, (2014), "Work Life Balance among Women Bankers - A Conceptual, Theoretical and Literature Framework", Global Journal for Research Analysis, 3(12): pp.126128.

2. Dev, G.N., (2012), "Employees' Perception on Work Life Balance and Its Relation with Job Satisfaction in Indian Public Sector Banks", International Journal of Exclusive Management Research, 2(2): pp.113.
3. Emmanuel, R. and Alluri Balaji, (2014), "Work-life Balance of Women in Banks-A Factor Analysis", International Journal of Marketing \& Financial Management, 2(1): pp.25-40.

4. Goyal, K. A. and Arpita Agrawal Babel, (2015), "Issues and Challenges of Work Life Balance in Banking Industry of India", Pacific Business Review International, 8(5): pp.113-118.

5. Lalita Kumari, (2012), “Employees' Perception on Work Life Balance and It's Relation with Job Satisfaction in Indian Public Sector Banks", Indian Journal of Economics and Management Research, 2(2). pp.113.

6. Mary Julia Sabarmati and Rajani Babu, R., (2015), "Human Resource Management Practices in Selected Private Sector Banks in Pondicherry - A Special Reference to Work Life Balance of Women Employees", International Journal of Advanced Scientific Research \& Development (IJASRD), pp.104-110.

7. Upasana Joshi Seth, (2014), "Influence of Work Life Balance on Organizational Commitment: A Comparative Study of Women Employees Working in Public and Private Sector Banks", European Journal of Business and Management, 6(34): pp.215-219.

8. Baridhara, V. and Vasanth, S., (2012), "Work Life Balances A Source of Job Satisfaction - An Exploratory Study on the View of Women Employees in the Service Sector", International Journal of Multidisciplinary Research, 2(3): pp.450-458.

9. Vijaya, T.G. and Hema Malini, R., (2012), "Impact of Work Life Balance on Organizational Commitment among Bank Employees", Asian Journal of Research in Social Science \& Humanities, 2: pp.159171.

10. Vijayalakshmi, P.S. and Amusia, M., (2015), "A Study on Quality of Work Life among Employees of Public Sector Banks in Tiruchirappalli District", Journal of Exclusive Management Science, 4(3): pp.1-12.

\section{Author Profile}

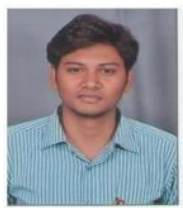

Dr. C. NAGA GANESH, Assistant Professor, G. Pullaiah College of Engineering and Technology Kurnool, (Andhra Pradesh), India.

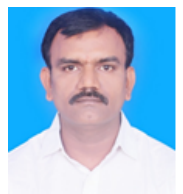

Dr. NAGARAJA. P. Associate Professor, Dr. B. R Ambedkar Institute of Management and Technology, Baghlingampally, Hyderabad (Telangana), India.

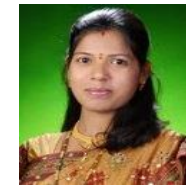

P. SUMALATHA, Assistant Professor, Dr. B. R. Ambedkar Institute of Management and Technology, Baghlingampally, Hyderabad (Telangana), India.
Published By: Blue Eyes Intelligence Engineering

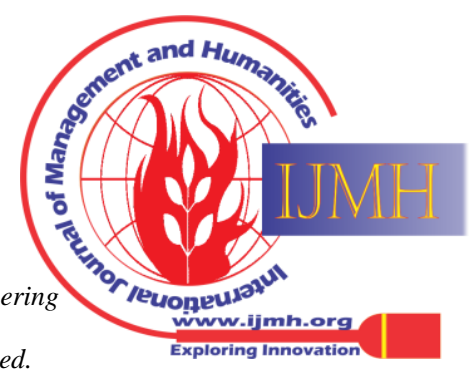

